ISSN 2504-1916

VOL. 16/1 (2017), 60-80

\title{
Jazz Education in Western Switzerland in the 1970s and 1980s
}

\author{
Formal, Non-Formal or Informal Learning Settings?
}

\author{
Monika Piecek, Angelika Güsewell
}

\section{Introduction}

$\mathrm{T}$ oday a large part of music learning takes place outside of schools, in situations where there is no teacher, and in which the intention of the activity is not (primarily) to learn about music, but to play it, listen to it, dance to it, share it with others, or be together with it. ${ }^{1}$ Recent technological developments and the increasing impact of the media further enhance this trend. ${ }^{2}$ Consequently, the focus of musical education research has shifted during the last decade-just like education research in general-from teaching to learning, and consequently from teacher to learner, from how to teach and the outcome of teaching to what and how to learn. ${ }^{3}$ Among others, this shift has led to increased interest in not only formal learning situations within institutional settings, such as schools or music schools, but also informal learning practices, wherever they take place. $^{4}$

Formal and informal learning can be conceived and defined differently, depending on the aspects of learning in focus. Drawing on a literature review, Folkestad identified four definitional

The authors wish to thank Susanne Abbuehl and Jean-Pierre Schaller for their support within the scope of data collection and analysis, as well as their helpful comments on an earlier version of this manuscript.

1 See for example Douglas Lonie and Luke Dickens, 'Becoming musicians: situating young people's experiences of musical learning between formal, informal and non-formal spheres', Cultural Geographies 23, no. 1 (January 2016), 87-101; Florence Eloy and Ugo Palheta 'Cultures juvéniles et enseignement musical au collège', Revue française de pédagogie 163 (2008), 39-50; Lucy Green, Music, Informal Learning and the School: A New Classroom Pedagogy (Aldershot and Burlington: Ashgate, 2008); Winifried Pape, 'Das Internet als Musikmedium Jugendlicher im Kontext sozialisatorischer Fragestellungen', in Rollenspiele. Musikpädagogik zwischen Bübne, Popkultur und Wissenschaft. Festschrift für Mechtild von Schienbeck rum 65. Geburtstag, ed. Thomas Erlach and Burkhard Sauerwald, (Bern: Peter Lang, 2014), 281-295.

2 Göran Folkestad, 'Formal and informal learning situations or practices vs formal and informal ways of learning', British Journal of Music Education 23, no. 2 (July 2006), 135-145.

3 Ibid.

4 See ibid. as well as Lucy Green, How popular musicians learn: a way abead for music education (Aldershot: Ashgate, 2002); Sidsel Karlsen and Lauri Väkevä, eds, Future prospects for music education: Corroborating informal learning pedagogy (Newcastle upon Tyne: Cambridge Scholars Publishing, 2012). 
aspects (that complement each other): the learning situation or context (where does learning take place?), the learning style (what is the character, the nature or the quality of the learning process?), the ownership (who decides what to do, as well as how, where and when) and the intentionality (is the mind directed towards purposeful learning or is learning a by-product of doing?). ${ }^{5}$ Some authors are also interested in the outcomes of the learning process, asking the question: Is the learner able to verbalise what he or she knows, or does he or she act adequately without being able to explain why and how? ${ }^{6}$

On the basis of these considerations, formal learning can be defined as learning that occurs within an organised and structured context (e.g. a school or a conservatoire), is based on a curriculum (structured in terms of learning objectives, duration, content, method and assessment), takes place under the direction of a teacher who leads and carries out activities designed to effect a change in the learner, and leads to a formal recognition, such as credit points or a qualification. ${ }^{7}$ The informal learning setting, in turn, contains both planned and unplanned learning activities resulting from daily life situations and is highly related to the personal learning drive and motivation of the individual learner who engages in specific activities just for the sake of the experience itself. It is not structured in terms of formally described learning objectives or progressively complex steps and does not lead to certification. ${ }^{8}$

Some authors ${ }^{9}$ suggest that formal and informal learning should not be regarded as a dichotomy, but rather as the two poles of a continuum that features many intermediate and hybrid forms of learning, an idea that led to the description of an intermediate third type of learning, namely non-formal learning. ${ }^{10}$ Non-formal learning refers to any organised educational activity that usually takes place outside the established formal education system and is highly contextualised. It is intended to serve identifiable learning clienteles and objectives (possibly tailor-made, adapted to the needs of the specific learner group). Non-formal learning is typically

5 Folkestad, 'Formal and informal learning situations'.

6 See for example Peter Mak, Learning music in formal, non-formal and informal contexts. www.emc-imc.org/ fileadmin/EFMET/article Mak.pdf (accessed 24 October 2017)

7 Folkestad, 'Formal and informal learning situations'; Mak, Learning music.

8 Folkestad, 'Formal and informal learning situations'; Mak, Learning music, and Lucy Green, 'Informal learning and aural learning in the instrumental music lesson: a research-and-development pilot project", in Future prospects for music education: Corroborating informal learning pedagogy, ed. Sidsel Karlsen and Lauri Väkevä (Newcastle upon Tyne: Cambridge Scholars Publishing, 2012), 161-195.

9 Mainly in the field of pedagogy. However, music learning and teaching has also drawn considerable attention of ethnomusicologists as well. The question of how informal learning of music occurs through enculturation processes is largely discussed in the ethnomusicological literature; there is less interest in what is considered as formalised music training in Western art music. See Graham Welch et al., 'Mapping music education research in the UK', Psychology of Music 32, no. 3 (July 2004), 239-290; Laudan Nooshin, ed., The ethnomusicology of Western Art Music (London and New York: Routledge, 2014); Timothy Rice, 'The ethnomusicology of music learning and teaching', College Music Symposium 43 (2003), 65-85.

10 See Haralabos Fragoulis, 'Innovations to address the challenges of lifelong learning in transition countries', in Lifelong learning: which ways forward? ed. Danielle Colardyn (Utrecht: Lemma, 2002), 154 167; Mak, Learning music. 
conceived on a short-term (i.e. less than one year) and part-time basis, and is not necessarily credentials-based; furthermore, non-formal curricula are less structured, in terms of the learning objectives, content, method and assessment, than formal curricula. ${ }^{11}$

Since the creation of conservatoires in the $19^{\text {th }}$ century, music teaching and learning in the field of classical music followed formal instructional approaches and mainly took place in formal settings. In contrast, extra-institutional informal learning was the norm for jazz teaching until the creation of the first jazz schools. As a consequence, formal education has long remained controversial among jazz musicians. The myth of the uneducated genius who plays from the bottom of his or her heart was-and still is-deeply rooted. Except for a few precursors, such as the German musician Alfred Baresel who published his Anleitung zum Spielen, Improvisieren und Komponieren moderner Tanzstücke as early as 1925 or the director of the Hoch'sche Konservatorium in Frankfurt who caused a sensation in 1927 with his idea to open a jazz class in his institution, little pedagogical activity in the field of jazz was undertaken until after World War II. ${ }^{12}$ In the European context, it was from 1965 onwards that jazz education programmes and institutions appeared with increasing frequency and that jazz learning and teaching entered a process of progressive formalisation and institutionalisation.

Three different models or directions of development, co-existing in the different national contexts, can be distinguished. On the one hand, full-fledged and independent educational programmes in jazz were gradually adopted as an integral part of the curriculum in many conservatoires across Europe. In spite of the more or less powerful resistance against jazz in academia, formal jazz education programmes were elaborated in newly founded jazz departments in many conservatoires. Thus, in Austria, the Jazz Institute of the Music Academy in Graz was set up in 1965, and the jazz department of the Vienna Conservatoire opened its doors three years later. The Austrian State Conservatoire in Carinthia and the Bruckner Conservatoire in Linz launched their jazz departments in 1984 and 1988 respectively. On the other hand, some conservatoires offered jazz courses without setting up proper jazz departments and jazz curricula. In France, for example, 1968 saw the opening of jazz classes in the National Conservatoire for the Marseille region, and in the early 1980s' jazz classes were available in the National Schools of Music in Angouleme and Avignon. In 1982 a survey conducted by National Centre of Musical Action (CENAM) established that 34 out of 160 public music education institutions offered jazz courses. ${ }^{13}$ Finally, autonomous ${ }^{14}$ jazz schools started to emerge. For instance, the Swiss Jazz School in Bern, set up in 1967, emphasised its institutional autonomy from the

11 Mak, Learning music.

12 See Bruno Spoerri, 'Vom Autodidakten zum Professor an der Fakultät Jazz - die Jazzschulen', in Jazz in der Schweiz - Geschichte und Geschichten, ed. Bruno Spoerri (Zürich: Chronos 2005), 342-352.

13 Data reported by the Centre d'information et de ressources pour les musiques actuelles (Irma): Pascal Anquetil, Jazz en France: Jazz en chiffres, published 26 April 2006, www.irma.asso.fr/jazz-en-francejazz-enchiffres.

14 Schools completely independent from established musical institutions, founded to offer nothing but a jazz (or modern music) curriculum. 
beginning, defining itself as the 'first independent jazz school in Europe'. ${ }^{15}$ Likewise, associative or private jazz schools, such as the Centre d'Information Musicale (CIM), the Institut Art Culture Perception (IACP), the Association Rencontre pour la Pédagogie et l'Enseignement du Jazz (ARPEJ), were created in France, more specifically in Paris from the late 1970s. Some of these autonomous schools were exclusively devoted to jazz (e.g. the Swiss Jazz School), whereas others were stylistically more open, including rock, pop, or electronic music (e.g. the Luzern Jazz School or the Rhythmic Music Conservatory, Copenhagen). Part of the institutions offered only professional training programmes; others were open to diverse pupils, including beginners.

The present study aims at taking a closer look at the transition from traditional, informal learning to what are considered as more formal realms of learning in jazz education in a very specific context, namely Western or French-speaking Switzerland (i.e. Swiss Romandy). Three main questions will be examined. First, what institutions and learning settings did appear, when, and in which circumstances? Second, how formal or informal were these settings and their respective instructional strategies? In other words, where could they be placed on a continuum between those two poles? And third, how did the first generation of professional jazz students set up their training in this emerging, new educational context, with what aims and with what results?

The first part of this article will therefore address the Swiss jazz educational landscape at the nascent period of institutionalised jazz education: the creation of first jazz programmes in the German-speaking part of Switzerland, the context and the chronology of the foundation of jazz schools and jazz departments in Swiss Romandy, and the formal, non-formal, or informal character of the different types of jazz learning structures that emerged in this particular context. In the second part of the article, the musical training trajectories of nine students who attended the new settings for jazz learning will be analysed. Special attention will be paid to learning practices, skills transfer and the access to and appropriation of music learning environments. Addressing these questions should complement the understanding of the implementation and expansion of institutionalised jazz education, as well as the processes by which jazz was learnt and taught in the 1970s and 1980s in Swiss Romandy.

\section{The first jazz education structures in Swiss Romandy}

To understand the emergence of formalised jazz instruction in Swiss Romandy, it is necessary to start with a short overview of the establishment and development of curricular jazz activities in the German-speaking part of Switzerland as of the 1960s. Drawing on the existing literature, the progressive establishment of the first jazz programmes in Switzerland will be portrayed briefly. From there, the circumstances in which jazz entered the process of formalisation in Swiss

15 'La SJS est la première école de jazz autonome d'Europe proposant l'offre d'un enseignement continu de musique'. Swiss Jazz School, 'Curriculum vitae de la SJS, accessed 24 October 2017, www.sjs.ch/ curriculum-vitae-de-la-sjs/?lang=fr. 
Romandy will be explored on the grounds of interviews and documentary analysis of schools' archives. Finally, two educational models that emerged consecutively in Swiss Romandy will be compared in the light of the formal-informal spectrum.

\subsection{Precursors ${ }^{16}$}

The Musik Akademie Zurich was the first Swiss school to offer an introduction to jazz music as of 1935. The first class started with 23 participants and seems to have been highly successful, as the number of students more than doubled in 1947 (i.e. 46 pianists, 6 saxophonists, and 3 percussionists). The jazz class seems to have continued until 1962, when it was last mentioned. In Basel, the pianist Robert Suter had a mandate in the 1940s to teach jazz at the Conservatoire, and in French-speaking Switzerland, the private Lycée Musical in Geneva is known to have started jazz courses in 1941.

Apart from these few institutionalised early offers, until the 1960s, Swiss musicians interested in learning jazz did so autodidactically, by playing with experienced colleagues, by listening to recordings and trying to copy them, and by constantly elaborating and testing themes, harmonic sequences, or improvisation concepts. Usable musical materials were hardly purchasable until the 1950s, and today's realbooks still a long way off. Therefore, passing musicians sometimes made their music notebook with compositions or transcriptions available for copy (by hand) to interested colleagues. ${ }^{17}$ In 1948, a small introductory booklet by Jan Slawe was edited by the Basel National-Zeitung; it provided jazz novices with some fundamentals. ${ }^{18}$ From 1952, a few music books with transcriptions of jazz standards were sold expensively by a Geneva importer. One year later, the Berendt, ${ }^{19}$ a book that is still in use nowadays, was published and rapidly experienced enormous success: technical terms were explained to the beginner and the jazz history systematised. ${ }^{20}$ Finally, the Zürcher Amateur Jazz Festival, a national platform and competition for young musicians, has to be mentioned, as it allowed for meeting other musicians and sharing musical experiences with them, thus providing opportunities for comparison and inspiration. As more and more young musicians wanted to join the success of this event and were looking for expert advice, the context was ideal for the creation of the first jazz schools. In 1959 two schools were founded, one in Zürich, with the support of the

16 The history of jazz education in Europe is largely unrepresented in the literature. The case of Switzerland is even less well documented. This section is thus based on the only historical study published prior to the time of writing: Spoerri, Jazz in der Schwei\%:

17 Ibid., 342-352.

18 Jan Slawe (Jan Sypniewski), Einführung in die Jazzmusik (Basel: National-Zeitung, 1948).

19 Joachim Berendt, Das Jazz̧buch: Entwicklung und Bedeutung der Jažmusik (Frankfurt am Main: Fischer, 1953).

20 Spoerri, Jazz in der Schweiz, 342-352. 
Lebensmittelverein ${ }^{21}$ Zürich, and another in Basel, with the support of the Allgemeiner Konsumverein. Two years later, in 1961, the regional Coop-Genossenschaft started its own school in Bern.

\subsection{Institutionalisation and professionnalisation of jazz education}

In the meantime, first jazz schools had been created in the United States as well. Mainly the Berklee College of Music in Boston (dating back to 1945) was widely recognised and awarded recognised Bachelor's degrees from 1966. ${ }^{22}$ Heinz Bigler, the first Swiss musician who studied there, founded the 'Swiss Jazz School' in Bern on his return in 1967. What distinguished this specific Swiss jazz school from all previous ones was the adoption of Berklee's proven curriculum (40 minutes of instrumental tuition, 90 minutes of theory, and one evening of bigband training a week) and teaching materials. In 1977, the Swiss jazz school diploma was recognised as professionally qualifying, and thus this school became the first independent jazz education institution in Switzerland to earn a status equivalent to the classical conservatoires. The next schools to be opened in German-speaking Switzerland were the Jazzschulen Luzern (1972), Zürich (1977), St. Gallen (1982), and Basel (1986). All these jazz schools had a great success and featured a very positive development during the 1970s and 80s. The Lucerne Jazzschule for example started in 1972 with four teachers and 60 pupils. Five years later, in 1977, there were 20 musicians teaching, and in the mid-1990s, 400 pupils were enrolled. ${ }^{23}$

\subsection{Creation of jazz educational structures in Swiss Romandy}

As can be seen from Figure 1, the proliferation and growth of jazz instruction institutions described in the previous sections also occurred in Swiss Romandy. However, the trend started a few years later than in some European countries and German-speaking Switzerland, namely in 1975. With respect to the institutional attachment, the three distinct developments outlined previously in the European context - namely the emergence of autonomous jazz schools, the foundation of jazz departments in conservatoires, and jazz courses offered by music schools or conservatoires without the setting up of proper jazz departments - appear to have been relevant in Swiss Romandy as well.

21 'Konsumvereine', that is cooperative societies, were founded in many Swiss towns in the second half of the $19^{\text {th }}$ century with the aim to represent the interests of consumers and to keep the prices of daily goods low by circumventing intermediaries. The 'Allgemeine Consum-Verein Basel' was founded in 1865, the 'Lebensmittelverein Zürich' in 1878. In 1890, many local societies were grouped under the 'Verband Schweizerischer Konsumvereine'. Konsumvereine not only provided their members with affordable food, but also funded banks, journals, and residential cooperatives. In 1923, a cooperative seminar was even established, not only to offer collaborators basic and continuing education, but also with the idea to provide the general population a holistic education. Coop, the second largest Swiss retailer that emerged in 1969/70 from the merging of regional 'Konsumvereine' continued this tradition in the form of its 'Freizeitwerk' (leisure workshop centre).

22 Berklee College of Music, 'A Brief History', www.berklee.edu/about/brief-history.

23 'Verein Jazzschule Luzern', accessed 24 October 2017, www.vereinjsl.ch/news.htm. 


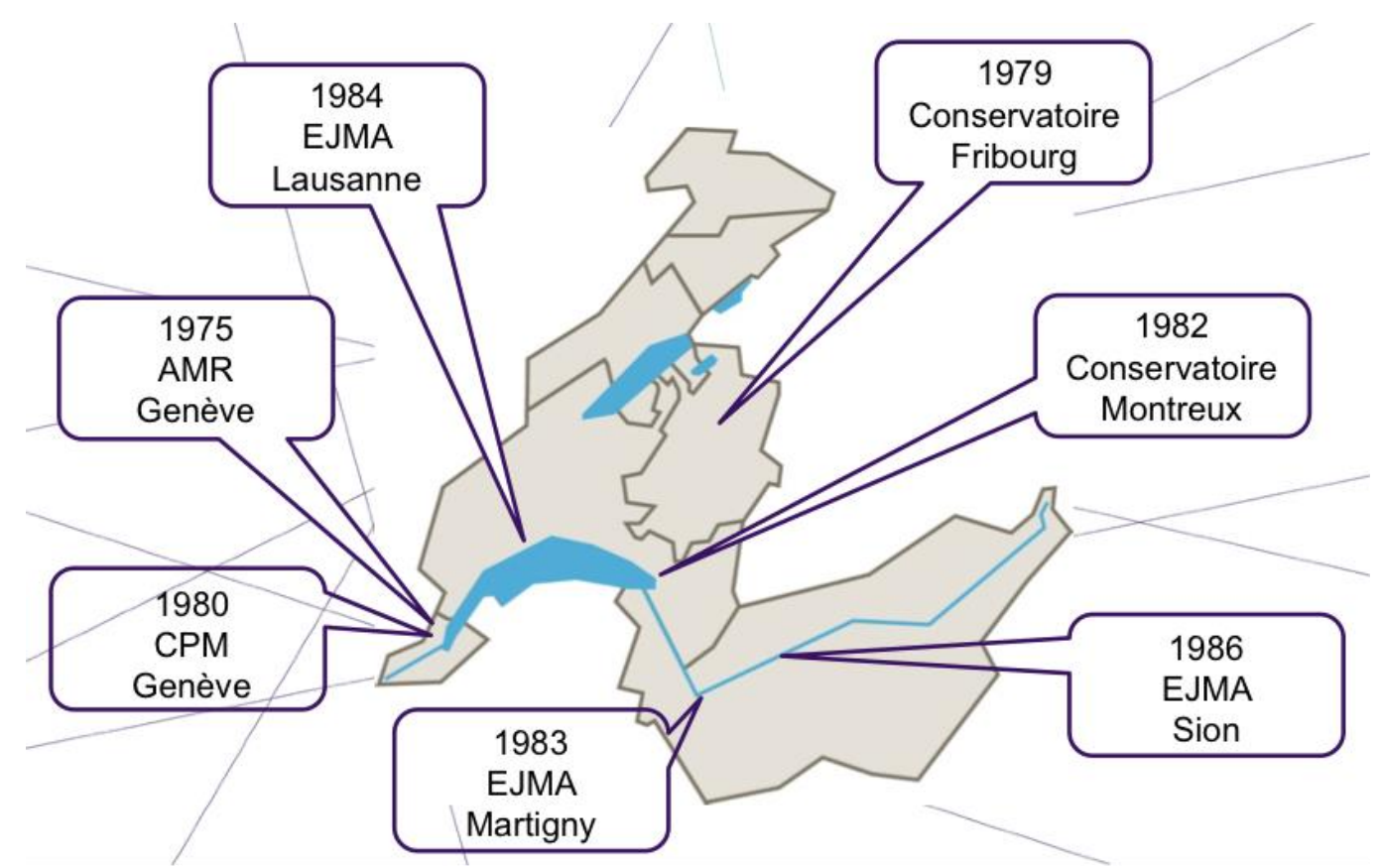

Figure 1: Creation of jazz educational structures in Swiss Romandy in the 1970s and 1980s. AMR = Association pour la Musique de Recherche; CPM = Conservatoire Populaire de Musique; EJMA = Ecole de Jazz et de Musiques Actuelles. The year of foundation is indicated.

The first institution to propose jazz classes was the Association pour la Musique de Recherche (AMR, Geneva), which established a specific educational approach to jazz from 1975 by implementing collective musical practice in small groups of musicians led by a teacher (without one-to-one tuition). In the following years, jazz sections were created in three conservatoires. The jazz section of Conservatoire de Musique de Fribourg was opened to all students, including jazz beginners (mainly classical music students who switched to a different field of study), as of 1979. In Geneva, the Conservatoire Populaire de Musique (CPM) offered jazz courses from 1970 onwards and then decided to organise a more structured jazz curriculum in 1980 by defining levels and by making it compulsory to undergo assessment at regular intervals. At that time, the CPM offered a range of instrumental and theoretical classes including courses such as introduction to jazz, arrangement and jazz history as well as solfege and harmony classes. ${ }^{24}$ Finally, the Ecole Jazz. Montreux (EJM) opened its doors in 1982.

In the following years, the jazz school Ecole de Jazz et de Musique Actuelle (EJMA) opened branches in three Swiss Romandy towns: Martigny (1983), Lausanne (1984), and Sion (1986). ${ }^{25}$ Courses were offered mainly by musicians from Lausanne, and the teaching was split into three

24 Of note is the 1989 regrouping of the activities of the CPM's jazz school and the AMR Workshops: a contract was concluded to avoid any competition and to ensure the complementarity of the programmes. The CPM specialised in theory classes and individual instruments, whereas the AMR specialised in group classes.

25 The Martigny and Sion branches constituted EJMA-Valais that was institutionally independent of EJMA-Lausanne. 
stages: preparatory, certificate, and diploma. ${ }^{26}$ The number of students attending EJMA soon exploded. In 1984, a total of 30 students were studying at EJMA Lausanne, whereas the number of students enrolled during the 1987/88 academic year rose to more than 400 , including some 30 professional students.

\subsection{The formal-informal spectrum: comparing two types of learning settings}

It is now an opportune moment to discuss how formal or informal the newly created jazz educational settings and their respective instructional strategies were in the 1970s and 1980s in Swiss Romandy. To answer this question, the material available in the archives of four different schools (i.e. course programmes, press articles, enrolment registers), namely AMR, CPM, EJMA Lausanne, and $\mathrm{EJM}^{27}$ as well as interviews conducted in 2014 and 2015 with several 'pioneers' of the time (i.e. school directors, teachers, and students) were analysed in the light of the literature on formal, non-formal and informal education. ${ }^{28}$ This analysis led to a tentative placing of the four schools on the formal-informal continuum, with the jazz departments of CPM and EJM lying near to the formal, the AMR ateliers lying close to the informal end. EJMA turned out to be hard to position, due to the particularly fragmentary nature of its archival material. ${ }^{29}$ However, on the basis of the little available, it seems that this school combined characteristics of both formal and informal education, and is thus best considered as lying 'in-between', that is as a non-formal learning setting.

The context of creation and the teaching practices of EJM and AMR will now be discussed in detail, in order to explain why the first was considered to lie near to the formal, the second to lie near to the informal end of the continuum. EJM was chosen rather than CPM because archive material and thus information available proved to be more complete.

\subsubsection{The creation of AMR and EJM}

Both AMR and EJM offer organised knowledge acquisition structures, designated explicitly as a learning context (these two elements are characteristic of formal learning). However, they are

26 EJMA (from 1983) and EJM (from 1990) offered their students the possibility to complete their studies with a diploma or certificate. However, these degrees were not formally recognised by the Swiss Confederation and thus not professionally qualifying. The professional training launched in 1997 in Geneva as a joint initiative of CPM and AMR was (and still is) recognised only on the cantonal level. Nationally recognised bachelor's and master's degrees could be awarded only from 2006, with the creation of the jazz department of the Haute Ecole de Musique Vaud Valais Fribourg.

27 Four schools representing the jazz educational landscape of the 1970s and 1980s in Swiss Romandy were selected for this research project: two conservatoires offering jazz programmes and two jazz schools.

28 Espescially Folkestad, 'Formal and informal learning situations'; Fragoulis, 'Innovations'; Green 'Informal learning and aural learning'; Mak, Learning music.

29 As the archives proved to be incomplete, comprehensive documentation could not be compiled for each institution. EJMA turned out to have archived only the data of the 'professional' (i.e. delivering a diploma) section, which did not allow for a thorough understanding of its functioning in the 1980s. 
radically different in terms of the institutional context at the time of their founding and the kinds of training proposed.

The Association pour la Musique de Recherche (later renamed Association pour la musique impRovisée) was created in 1973 by a group of young musicians of 'all levels ${ }^{30}$ who were brought together by a shared passion for jazz. The association set out to meet the need for musical rehearsal venues and regional diffusion, and aimed to develop and promote the 'shared passion' 31 for a new area of musical expression. In the beginning, musicians met in a large format workshop to exchange ideas and practices, to help each other improve and to work on expression. However, very soon, the question of how to transfer knowledge to less experienced musicians was raised. By 1975, the workshops had the clear aim of developing transfer (i.e. teaching) within the scope of group work, as ensembles. In general terms, the AMR programmes were geared also towards musicians who did not have a basic grasp or understanding of jazz. AMR defined itself as not only a place for rehearsal (i.e. individual and group work) or musical production (i.e. jazz diffusion through concerts), but also a place for musical teaching. It was both a place for knowledge transfer and a platform for musical encounters. As such, and as an important actor on the Geneva music scene, it offered opportunities for musical socialisation and for the acquisition of musical knowledge through the immersion in daily musical practice (or what Green names enculturation ${ }^{32}$.

Ecole Jazz. Montreux (EJM) was born out of the initiative of young musicians recently graduated from the Swiss Jazz School in Bern, who set out to create an organised jazz teaching structure through affiliation with a pre-existing musical institution. So, in 1982, EJM first came into existence as a section of the Conservatoire Classique de Montreux (already 67 years old at the time). From the outset, EJM was exclusively a place for teaching and learning, and was set up with the clear intention of offering structured learning. In this respect, it followed the model of the classical music conservatoire where learning takes place out of context, in situations that do not represent 'real' musical practice.

Both schools met with difficulties in obtaining state subsidies. As a result, they moved around a lot (especially AMR) and were constantly faced with difficulties in finding new premises. These difficulties slowed the development of the AMR workshops, despite the increasing interest of students (as measured by growth in enrolment). In 1982, the AMR finally secured some space in the 'Sud des Alpes' building, making it possible for a musical centre to be set up (i.e. the grouping of all its activities in one place as well as the independent management thereof) and for greater numbers of students to be enrolled. So, what was 75 students in 1980 became 137 in 1981, and 230 in 1989. Likewise, the three workshops offered initially became 43

30 'Tous niveaux confondus'. AMR, 'Un peu d'histoire', accessed 24 October 2017, www.amr-geneve.ch/ un-peu-dhistoire.

31 'Passsion commune'. AMR, 'Un peu d'histoire', accessed 24 October 2017, www.amr-geneve.ch/unpeu-dhistoire.

32 Green, Music, Informal Learning and the School, p. 5. 
over the same period. At EJM, the tipping point came in 1984, when the school was able to hire three extra rooms thanks to an increase in subsidies from the local authorities. This meant that the 15 or so students who signed up the first year became around 60 in 1983, and 150 in 1984.

\subsubsection{Teaching and learning practices}

At EJM, the progressive formalisation of teaching is directly linked to the sharp rises in cohort sizes, which led the organisers to 'structure the classes' ${ }^{33}$ (i.e. implement a system whereby the students were divided into classes), to widen the number of courses offered and to supplement the training programme. This formalisation process led to the creation of a structured (i.e. linear and sequential) curriculum and from there to the awarding of non-vocational education certificates to students. The students could choose whether to follow individual (instrumental) classes only or to take on a more complete course (leading to a certificate) that included theory classes (e.g. rhythmic solfege, harmony, arrangement, composition) as well as the option of group classes (i.e. workshops). The learning process was led by qualified musicians who played regularly. Lastly, learning outcomes were assessed in the form of a final exam at the end of the training programme. ${ }^{34}$

All these elements seem to reflect a typical formal learning scenario. EJM, however, did not define (at least not at the very beginning) specific entry skills, a key element in the strict definition of formal teaching. As one of the EJM teachers explained, ' $t$ ]here were no initial exams. We guided students at the outset and then waited to see if they reached a certain level and then pushed them further forward. ${ }^{35}$ Furthermore, the actual implementation of formal principles was not systematic. According to one of the EJM founders, the training stages were not 'very clear' (especially at the very beginning). A part time course (of around 3-4 hours a week $^{36}$ ) was established step by step, but the evident will to set up a structured training course was accompanied by the refusal to let it be 'extremely detailed' or 'overly formatted' curricula like at Berklee College of Music in Boston. Furthermore, the teachers, despite being qualified musicians, did not necessarily have pedagogical training: 'We kind of overlooked the issue of how to teach. I mean, we wanted to offer classes and everything, but we just didn't know really how we were going to go about doing it. ${ }^{37}$

33 'Structurer les cours', interview with one of the EJM founders.

34 The certificate exam comprised a private instrumental exam with a technical part, sight reading, and the application of theory to an instrument, lasting around 25 minutes, and a 30-40 minutes group recital. This exam had to be supplemented by the final theory certificate (at the end of four years) and by two years of workshops.

35 Interview conducted with one of the EJM teachers on 11 June 2015 in Lausanne (anonymous).

36 (a) one instrument class of 40,50 or 60 minutes (choice of the student); (b) one 60-minute theory class; (c) one 60-minute workshop; (d) during the last two years, a 60-minute arrangement/composition class.

37 Interview conducted with one of the teachers on 11 June 2015 in Lausanne (anonymous). 
At AMR, the exponential increases in the number of students did not lead to the setting up of a structured curriculum leading to a certificate. From the outset, the teaching was based solely on work in small groups (4-5 musicians led by a workshop leader). The students invested directly into the group practice from the beginning of their time at AMR. They could choose freely among the binary and ternary workshops, ${ }^{38}$ be-bop workshops, free-jazz workshops, singing workshops, jazz-combo workshops, salsa workshops and even big band workshops. ${ }^{39}$ The organisation of and attendance at the different workshops depended on the instruments required to put together musically meaningful ensembles, the availability of teachers and students, as well as the 'compatibility of levels' of participants. The preferences of learners (with regard to teachers and class companions) were taken into account as far as possible and 'migration' between workshops, due notably to the progress or changing interests of students, was not rare. Nevertheless, as one workshop founder mentions, 'most of them went along with what we offered them. ${ }^{40}$

There were then both formal and less formal aspects to the way teaching was organised at AMR. On the one hand, the goals and targets of each student were set out individually by the workshop leaders who were themselves mainly, if not entirely, self-learners and therefore paid special importance to learning by doing. The focus was therefore on musical practice and not on theoretical notions. Teachers saw as much (if not more) value in the 'accidental' learning and personal musical research of each individual student than in intentional learning outcomes. On the other hand, the transfer of knowledge remained a vertical process (more or less, according to the teacher at hand) and the targets, workshop content and teaching methods stemmed from the teachers' choices, even if it was possible to envisage a certain flexibility in the roles related to the specific subjects being taught. The journal Viva la Musica explained it this way in 1979:

Without doubt many technical aspects can be demonstrated in a relatively traditional mannerinstrumental techniques, scale and chord, tone, phrasing and other exercises-but, not wanting slowly to become stereotypes, students weren't allowed to imitate improvisations as if they were interpretations of sheet music. The "teacher-student" relationship itself must be continuously improvised, and the roles then become much more flexible and adaptable.'41

Taken together, these characteristics fit in with the definition of non-formal learning given by Mak, ${ }^{42}$ and AMR thus is best conceived as an example of this intermediate category.

38 A ternary rhythm is characteristic of jazz, while fusion, funk, blues, soul as well as latin music are mostly played in binary rhythm. Thus, AMR's binary workshops proposed a range of popular AfroAmerican music.

39 Other workshops were developed over time and not necessarily continued.

40 Interview conducted with one of the teachers on 15 June 2015 in Geneva (anonymous).

41 Viva la Musica. Périodique d'information de l'AMR 24 (March/April 1979).

42 Mak, Learning music. 


\subsubsection{Formal, non-formal or informal?}

Mak complemented the formerly dichotomous vision of learning and teaching by introducing non-formal as an intermediate category between formal and informal. He thus introduced the idea of a continuum that takes into account the permeability of the categories as well as the mobile nature of their respective boundaries. Mak's dynamic model helps to understand the convergent elements of the two Romandy learning settings discussed above, despite them seeming disparate at first sight. Both cases demonstrate the strong influence of informal practices on the practices found on the 'formal' side of the continuum. Furthermore, in both schools, the learning processes (not only the repertoire performed, but also, for example, the skills emphasised to the students) were highly dependent on the individual musical and learning experience of the teachers, all the more as the teachers were given no, or almost no, guidelines or instructions with regard to musical pedagogy by their employers.

It is clear that early institutional jazz transmission in Swiss Romandy cannot be neatly compartmentalised. The boundaries between the formal, non-formal, and informal education aspects were shifting and permeable, meeting the changing context, as well as the changing needs of students and teachers. Given this flexibility and constant evolution, we could perhaps speak of a hybridisation or a dialectic process - to follow Folkestad's terminology ${ }^{43}$ —of educational strategies that moved from a more formal to an informal instruction and vice versa on their way towards progressive formalisation.

\section{Designing one's personalised training path: narratives of former students} What about the students' point of view? What were they looking for in these new education institutes? What expectations did they have in relation to the training? How did they experience their learning environment? And what place did the jazz school occupy in their longer learning path? In order to answer these questions and to explore the experiences and training paths of former jazz students, a list of professional musicians presently living in Swiss Romandy who might have attended the newly created jazz schools in the 1980s was established using available enrolment registers and the snowball sampling method. All of these musicians were contacted and shortly questioned about their training. Out of those who actually studied in Swiss Romandy during the target time frame, four women ${ }^{44}$ and five men $^{45}$ accepted to be interviewed. The nine semi-structured, in-depth interviews took place in autumn 2014. They lasted approximately one and a half hours each, and concerned family background, initial and subsequent professional musical training, professional integration, present situation, and work/family balance.

43 Folkestad, 'Formal and informal learning situations'.

44 As participants were guaranteed anonymity, names are changed. The four women interviewed were aged 46-58 (in 2014).

45 As participants were guaranteed anonymity, names are changed; the five men interviewed were aged 50-64 (in 2014). 


\subsection{Twisted and diverse training paths}

It emerged that the training paths of the nine musicians interviewed were highly diverse, with each musician reporting a unique, individual succession and combination of the existing, more or less formal jazz education programmes - in Swiss Romandy, or, less frequently, in Bern or abroad. A close analysis of these diverse trajectories evidenced four main patterns, that is, four categories of training paths. The first pattern concerned two musicians (Pierre and Marco) and was labelled 'AMR plus individual instrumental tuition': both musicians took private jazz piano lessons during secondary school, before starting to take part in AMR workshops after obtaining their baccalaureate. Although the first jazz schools or jazz departments either already existed or were being created in Swiss Romandy at that time, musicians Pierre and Marco did not attend them. Why? Was it a deliberate choice? According to Musician Pierre, 'at that time there weren't any jazz schools. Sure, there were places in New York and Los Angeles where you could become a jazz musician and a creator. But apart from that, there was no choice, you had to learn like that. $^{36}$ It appears that far from all musicians were aware of the newly created learning opportunities existing in Swiss Romandy in the 1980s.

The second pattern concerned two musicians and was labelled 'AMR plus conservatoire or jazz school.' This category groups two women (Anna and Yolanda) who did the major part of their training at AMR, in combination with several individual instrumental lessons or theory classes in a conservatoire jazz department or a jazz school, depending on where they were living. Anna is a perfect example of this category. She explains: 'I started the AMR group workshops when I was 18 [...] I went to lots of them. I reckon I did at least ten or so nearly. So, almost all my training was principally at AMR, and then just a few one-to-one classes at the Conservatoire Populaire. ${ }^{, 47}$

The third pattern grouped four musicians (Catherine, Thomas, Sophie, and René) and was labelled 'multitude of settings'. What the training paths of these musicians have in common is the roundabout of training opportunities of which they made use. In fact, these musicians could be described as 'training eclectics', choosing without prejudice what seemed to meet best their needs at a given time, mixing classical and jazz theory courses, travelling around to attend summer courses, taking lessons with different teachers whenever an opportunity showed up. The education path of Thomas exemplifies this pattern: he started playing classical trumpet as a child. When he was 15 or 16, he attended summer courses in the south of France and also his first AMR workshops. In parallel, he received instruction at the Conservatoire Populaire in Geneva, participating in a big band ensemble and attending harmony classes. He took individual lessons with different private teachers, who were not necessarily teaching his own instrument, also with a trumpeter teaching at the Swiss Jazz School in Bern, and even enrolled temporarily at ETM, Ecole des Technologies Musicales, in Geneva to learn harmony, arrangement, and synthesiser. In the

46 Interview conducted with 'Pierre' in August 2014 in Geneva (anonymous).

47 Interview conducted with 'Anna' in September 2014 in Geneva (anonymous). 
interview, he described his approach as follows: 'I borrowed from just about everywhere I could, without really getting into any system'. ${ }^{48}$

The fourth and last pattern concerns only one of the musicians interviewed. It was labelled 'studies abroad', as the distinctive feature of this learning biography was the decision to study at the Berklee College of Music. Oliver started playing percussion as an autodidact. He subsequently took flute lessons at the Fribourg conservatoire, in the classical section, so as to be able to replace his brother at his flute classes. When he discovered the jazz saxophone through recordings, he immediately bought a saxophone and started taking classical lessons, as there was no jazz teacher in Fribourg at the time. As soon as he found out there was a jazz saxophone teacher at EJM in Montreux, he enrolled there as well, studying classical and jazz saxophone in parallel. Within the context of the Montreux Jazz Festival, he took seminars 'with the people who came [for it], people who taught in the American schools', and was fascinated. 'Everything after that was a flash. It's what made me leave afterwards.' As soon as he had the opportunity, he left for Berklee. In his interview, he points to the differences between the jazz educational settings he had been exposed to in Swiss Romandy and the reality he discovered in the United States:

'The Swiss schools were the first of their kind and they weren't so bad. They wanted to copy the American schools, because they were the schools of reference. But they didn't have any way of securing the same infrastructure and so on. So, they got by with what they had. And that was all very well. But, really, when you enter a big school, you see there's everything. The structure is there and everyone finds what they are looking for.'49

\subsection{Self-construction of the professional training}

The preceding section showed that the musicians interviewed pursued a large variety of training paths, no two learning trajectories being identical. Each of them-depending on factors such as initial musical training and socialisation, instrumental level, musical and professional expectations, the jazz education settings already available, or their current place of residenceconstructed his or her personal 'curriculum'. Such curricular self-construction, seemingly a defining feature of jazz training in the 1980s in Swiss Romandy, is not explicitly mentioned in the literature on informal learning, but comes close to what Folkestad labels 'ownership' 50 and what Green describes as follows: informal learning always starts with music which the learners choose for themselves' as opposed to formal learning where the purpose is to introduce musical materials preselected by teachers. ${ }^{51}$

Instances of ownership or self-construction of musical learning can be found in the narratives of all musicians. The fact that eight out of the nine musicians interviewed reported

48 Interview conducted with 'Thomas' in October 2014 in Geneva (anonymous).

49 Interview conducted with 'Oliver' in October 2014 in Geneva (anonymous).

50 Folkestad, 'Formal and informal learning situations', 142.

51 Green, Music, Informal Learning and the School, 10. 
having developed an interest in jazz on their own-having respectively studied their instrument autodidactically for some time-fits in with the literature and therefore is not surprising. However, six musicians mentioned the difficulties in finding out where it was possible to learn jazz within a school or with a teacher, which was unexpected: 'I think that in my time, you had to go looking for information. ${ }^{52}$ While it was clear at that time where and how to study classical music in Swiss Romandy, the same did not hold true for jazz: 'So, I started just briefly to look. But there was nothing... I mean, if you wanted to learn classical trumpet, "Fine, go to the conservatoire." No problems there. But if you wanted to play jazz, well, that meant going underground. You had to put out the feelers, see where things got interesting. ${ }^{53}$

The interviewees also addressed that the quality of the curriculum and the teaching offered in the newly created schools was variable, which meant the students had to assume individual responsibility for their training quality:

'Personally, I'd say the difficulty was just as much in that... you had to struggle, or to have things clear enough in your mind, to be able to receive quality instruction. Because the problem wasn't about having to search everywhere for it, it was about keeping the quality relatively steady. 54

Consequently, 'students' were often changing school or teacher-'that happened a lot back then, you'd do one year with one teacher and then two years with another, three with the next ${ }^{55}$-in order to receive new input and to combine approaches and ideas: 'So, actually, every element of my learning was chosen individually by going out there and getting it, sitting on the coat tails of the teacher, an American trumpeter passing through the region'. ${ }^{56}$ This strategy was all the more important as most teachers were not pedagogically trained, and thus could not offer the systematic, structured teaching sought by most of the interviewees. As a consequence, young musicians were constantly searching for exercises and practice techniques:

Now I see the students that graduate from the $\mathrm{HEM}^{57}$ s, you can see the extent to which they are accustomed to being told what to do. All they have to worry about is getting up in the morning and going to the place where they are told what to do. And what did we have to worry about? Finding a place where we could even find out what to do.'

Self-construction also implied self-discipline with respect to practice:

'And when I say training, I mean getting up in the morning, setting everything out on paper, I slogged it out for 15 hours a day. There was no getting up at eight. I'd get up at seven. I'd start at eight. 8 a.m. till 9 a.m., 9 to 10, 10 to 11, 11 to 12, and so on. It was crazy non-stop. ${ }^{58}$

52 Interview conducted with 'René' in October2014 in Geneva (anonymous).

53 Interview conducted with 'Thomas'.

54 Interview conducted with 'Thomas'.

55 Interview conducted with 'Catherine' in October 2014 in Geneva (anonymous).

56 Interview conducted with 'Thomas'.

57 Hautes Ecoles de Musique $=$ Music Universities.

58 Interview conducted with 'Thomas'. 
Finally, and this comes closest to Folkestad's concept of 'Ownership', ${ }^{59}$ self-construction meant learning, working, and experimenting, without teachers, with other young musicians and students: 'There was one class per week, but we wanted to play way more than that. So, we also set up these sorts of workshops, but run by ourselves. I mean, we met, we chose the level, the track, and we'd play together, just us, no teacher'. ${ }^{60}$

In summary, the 1980 s seems to have required great autonomy to successfully draw on the resources and opportunities available in Swiss Romandy. The musicians describe how they developed their educational progression through skilful combinations of different styles of music and learning opportunities. The characteristics and organisation of what were relatively new courses, together with the lack of pedagogical training and experience of the teachers led to a patchwork of short-term learning episodes. Students shifted between learning structures and learning spaces, finding individual solutions that met their individual needs:

'I realise that I used the structures a little, and maybe even the people. I mean I went to see them and when it was no longer interesting, that was it, I just switched off [...] What really happened was that I'd just slip in and out of the different classes on offer.' ${ }^{31}$

\subsection{Combining different non-formal learning settings}

As discussed in section 2.4, the newly created jazz educational structures of Swiss Romandy combined aspects of both formal and informal teaching and learning to different degrees, and are thus best defined as non-formal. A distinction was made between two prototypes or models of institutionalised jazz teaching in Swiss Romandy in the 1970s and 1980s: the AMR workshops located on the informal end, and the EJM's located on the formal end of the continuum of nonformal learning settings. The interviews revealed that most musicians reported having integrated into different learning settings that corresponded to or lay 'in-between' (e.g. EJMA) these two models, either in parallel, or successively, or even alternately. The question of interest is what made them do so.

Conservatoire jazz departments and the newly created jazz schools (such as EJMA), following the tradition of classical departments and music schools, offered theory courses and thus the opportunity to acquire the basic tools for understanding jazz. 'They ran a section on theory, and it went into more depth than we'd seen anywhere else. ${ }^{62}$ They also offered the possibility of taking individual instrumental lessons so as not only to improve individual instrumental techniques, but also to take advantage of teachers' backing and support: 'They were people who got behind us, they followed us, encouraged us. That was important. You need to have references'. ${ }^{3}$ The more or less structured and systematic education corresponded to some

59 Folkestad, 'Formal and informal learning situations', 142.

60 Interview conducted with 'Marco' in October 2014 in Geneva (anonymous).

61 Interview conducted with 'Thomas'.

62 Interview conducted with 'Catherine'.

63 Interview conducted with 'Oliver'. 
students' needs: 'It was so well set up that I just found it refreshing. More than anything, it was what I really needed', ${ }^{64}$ despite the existence of a dismissive stance towards jazz education programmes: 'There was always this idea of formatting at the jazz school back then. ${ }^{65}$ Indeed, conservatoires and jazz schools, though recognised as useful to acquire basic knowledge and skills, were not perceived as a musically stimulating environment: 'The Conservatoire Populaire had good classes, but there wasn't, there was no strong push to make better music. ${ }^{96}$

It was instead at AMR that students sought and found musical inspiration and stimulation: 'AMR used its meetings, jams, scenes, festivals, and it created a very, very stimulating effect. ${ }^{67}$ The workshops corresponded to the desire to play in a group and to share with others, to meet other musicians and to build a network: 'My aim in coming to Geneva to study was to meet people. And it was thanks to all the people I met that I created a network of people with whom I wanted to work and with whom I was able work. ${ }^{98}$ And, first and foremost, to learn how to improvise: 'At AMR, the philosophy was to be able... well, first to have a place where we could make music and play improvised music. This was the AMR philosophy, guiding people to improvise as much as possible', ${ }^{69}$ to learn the essence of jazz: 'Let's just say that in the workshops, I finally learned an essence of jazz, of the workings of the saxophone player, of the soloist, of developing my hearing. Whereas at the conservatoire, it was more like being in a school classroom, in fact. ${ }^{, 70}$

In summary, it appears that most students opted for both the AMR workshops and the training offered in jazz departments and jazz schools because these two types of learning settings, though both non-formal, offered different but complementary and equally important aspects and approaches of jazz education.

\subsection{Learning by doing: informal learning}

Alongside participating in different classes and workshops, all five male musicians reported learning practices near the informal end of the formal-informal spectrum. They attributed high training value to these practices and described them in terms of 'experience', not 'instruction', emphasising the importance of interacting with other musicians (especially in groups with elders, but also in peer-supported learning contexts) and of being immersed in a performance culture during their apprenticeship. Interestingly, such practices and experiences appear to a lesser extent or are absent in the narratives of the four female musicians. This is in line with the literature, which describes women's difficulties in being integrated and fully recognised as jazz musicians. ${ }^{71}$

64 Interview conducted with 'Oliver'.

65 Interview conducted with 'Thomas'.

66 Interview conducted with 'René'.

67 Interview conducted with 'René'.

68 Interview conducted with 'Sophie' in October 2014 in Geneva (anonymous).

69 Interview conducted with 'Sophie'.

70 Interview conducted with 'René'.

71 See Marie Buscatto, Femmes du jaz:: Musicalités, féminités, marginalisations (Paris: CNRS Éditions, 2007); 
We learn from the narratives of men that informal learning experiences can take place in diverse settings. Musician Pierre was 15 or 16 years old when his teacher told him: 'Listen, there's an orchestra that's about to need a new pianist. I think you should go and listen now. It'll be a learning experience for you. ${ }^{72}$ So, he went to observe the pianist for several weeks, and then started playing himself. Thomas played in youth big bands from the age of 15: 'In Geneva there were two big bands, large jazz outfits run by young people. And that turned out to be my schooling.' He continues:

'So, the big band continued the tradition of being a school. It was where you learned things like phrasing, articulation, and style. Even solos, and because solos are relatively short, there you could already start to play short ones, not like in a quintet where you have to play solos all night..73

Marco and Oliver emphasised the importance of playing in groups while studying: 'Early on I made myself play with others, in different formations. I always pushed myself towards different groups, and it turns out that that's the best way to learn. ${ }^{, 74}$ René had the opportunity to take part in concerts, although he had barely started learning to play: 'We were lucky to have had a workshop that was immediately added to the programme of the Cropettes festival ${ }^{75}$, we played in the hall... And there you go, with a most basic level, I wound up... me, on the big stage and surrounded by good musicians. ${ }^{76}$

Former students' narratives showed that different more or less formal learning and teaching environments were linked within what can be described as fragmented learning networks. Participation in community-based non-formal music practice gave almost all musicians access to valuable information about available learning possibilities in more formal settings. Vice versa, teachers suggested learners to join musical groups outside of schools and provided them with helpful tips and contacts.

\subsection{Expectations and outcomes}

What did young musicians expect from their professional training? Only one out of the nine musicians mentioned having had the clear intention to turn professional: 'I remember when I was in college, in my mind, everything was set. I knew I was going to make music. ${ }^{, 77}$ The others had a less determined vision: 'I had no... I mean, I don't remember having had a more specific

and Ursel Schlicht, 'Individuelle Musik auf Jazzbasis: Arbeitsbedingungen und Ausdrucksformen von Musikerinnen in Hamburg und New York', in Jazz und Gesellschaft: Sozialgeschichtliche Aspekte des Jaz: (Darmstädter Beiträge zur Jazzforschung, vol. 7), ed. Wolfram Knauer (Hofheim: Wolke, 2002), 135152.

72 Interview conducted with 'Pierre'.

73 Interview conducted with 'Thomas'.

74 Interview conducted with 'Oliver'.

75 Concerts and entertainment taking place in the Cropettes park (Geneva) every June since 1982.

76 Interview conducted with 'René'.

77 Interview conducted with 'Oliver'. 
plan. Sure, no one imagines a training course leading to job in that sense. It was more like a leisure exercise. ${ }^{78}$

Given such vagueness of ideas about professional and artistic futures, it is surprising that no fewer than five out of the nine musicians interviewed completed their training and received a jazz certificate or diploma. Two out of the nine musicians complemented their jazz studies with music education studies and hold a diploma for either early music education or school music. One musician obtained a diploma as a classical singer.

According to those musicians who received neither a diploma nor a certificate, the reasons lie partly in their own lack of interest or of awareness that such a grade might be of importance later on in their working careers, and partly in the fact that the curricula were not sufficiently well structured:

'As there was no proper predefined framework, with clear requirements, you could... Well, me at least, I slipped between the cracks when it came to certain requirements. That meant my weaknesses were never corrected. I never scrutinised my performance for those weaknesses, never told myself, "Careful. This might be dangerous. This right here could cause problems later on."”79

In the long term, it did turn out to be problematic not to hold a diploma. On the one hand, because it became increasingly difficult to find employment as a teacher due to recent changes in music school policies, ${ }^{80}$ and on the other hand because of self-doubts:

'I'd say that that was the difficult part for me. I mean, that there's... that there wasn't, neither for me nor for the institution, a finish line that told me that "That's it, you've graduated. You're a pro now." So, I have always had a reason to doubt myself.' 81

Those who obtained a diploma or a certificate agreed on the fact that such documents never had (and still do not have) any value for them as musicians, but were nevertheless important, as they allowed them to find and keep jobs as teachers. Furthermore, the act of certification was experienced and described as having had strong symbolic meaning: 'It was the end of my studies [...] I'd succeeded in my studies and I was, I was happy and so proud and everything. So, yes, at any rate, there was a very high symbolic value in it. ${ }^{82}$

\section{Conclusion}

Drawing both on the documentary analysis and on the in-depth, semi-structured interviews conducted with nine male and female musicians who received professional training in the 1980s, the present study is the first to take a close look at the period when jazz schools were first

78 Interview conducted with 'Catherine'.

79 Interview conducted with musician 'Thomas'.

80 Creation of Hautes Ecoles de Musique in 2005; implementation of the Loi sur les Ecoles de Musique in 2012.

81 Interview conducted with 'Thomas'.

82 Interview conducted with 'René'. 
created in Swiss Romandy. Apart from establishing a reliable chronology of the main schools' foundations, and thus of the step-by-step institutionalisation and formalisation of jazz education in Swiss Romandy in the 1970s and 1980s, this research aimed at examining how formal, informal, or non-formal the newly established learning settings were, and at shedding light on the processes of access to and appropriation of these new music learning environments.

It appears that jazz education in Western Switzerland in the 1970s and 1980s, despite the creation of jazz departments and jazz schools and regardless of the type of learning setting, was relatively far from a strict definition of formal teaching and learning. Although jazz schools or jazz departments gradually set up structured curricula, with clear objectives and a predefined sequence of courses to be attended, along with periodical checks of students' progress and learning successes; interviews with contemporary witnesses (directors, teachers, and students) demonstrate that the practical implementation of these curricula and associated new patterns of social organisation of musical learning practices was a long-lasting process and one certainly not completed in the 1980 s.

Several other aspects of jazz teaching appear to be stable throughout those early decades and across the respective teaching institutions in Swiss Romandy. First, possibly due to the lack of professionally trained teachers, there was a non-systematic approach to knowledge transfer and acquisition, resulting in difficulties for the students in acquiring a solid instrumental technique and a structured working method. Second, there was a dissection of the different elements of a comprehensive jazz education: with the theory classes (e.g. solfege, harmony, arrangement) being assigned to the jazz departments or jazz schools, with instrumental technique being taught within the scope of one-to-one tuition either in schools and jazz departments or by a private teacher, and with 'real' musical practice as well as improvisation taking place in the AMR workshops or in 'real-life' artistic contexts such as orchestras, big bands, bars and clubs. Third, despite the presence of teachers and the principle of vertical transmission in all of the learning contexts, students showed marked autonomy, ownership and curricular selfconstruction. Fourth, there was a pronounced regionalism, with very little awareness of or interest in existing, highly structured and exceedingly comprehensive training offers outside Swiss Romandy (e.g. Swiss Jazz School in Bern) or abroad (e.g. Berklee College of Music in Boston).

All of these characteristics correspond more to non-formal teaching and learning as defined by Mak: an organised educational activity that usually takes place outside the established formal education system, that is highly contextualised, intended to serve identifiable learning clientele and objectives (possibly tailor-made, adapted to the needs of the specific learner group), based on a less structured curriculum in terms of learning objectives, content, method and assessment when compared with formal curricula, mostly short term (less than one year) and part-time, and not necessarily credentials-based. ${ }^{83}$

83 Mak, Learning music. 
Our findings bring into question present-day tertiary jazz curricula. Such curricula offer a formal learning context the purposes, pedagogical approaches and outcomes of which are well specified. They aim at effective and efficient transmission of fundamental musical knowledge and skills with the help and guidance of qualified teachers. However, they are at risk of lacking the relevance and meaning of what is learned, as well as ownership and the time for artistic, 'real-life' activities outside school. Whereas the challenge in the 1980s was to develop further the formal aspects of jazz education, the challenge at the beginning of the $21^{\text {st }}$ century seems to be the integration of non-formal and informal learning opportunities into highly formal structures and curricula of professional jazz education institutions. As Mak writes, 'attitudes like openness to other people and work ethos are moulded in non-formal learning contexts', whereas in informal learning contexts 'the student is totally responsible for his learning and learning results. Learning here is strongly connected to personal needs and desires. Students learn to take responsibility, and take the lead in their professional development'. ${ }^{84}$

84 Mak, Learning music, 10-11. 